\title{
Inhibitory Effects of 4-(4-Methylbenzamino)benzoate on Adipocyte Differentiation
}

\author{
Jin Taek Hwang, ${ }^{1,2}$ Sanghee Kim, ${ }^{3}$ Bo-ra Yoon, ${ }^{1}$ Inwook Choi, ${ }^{1}$ and Sang Yoon Choi ${ }^{1,2}$ \\ ${ }^{1}$ Korea Food Research Institute, Seongnam 463-746, Republic of Korea \\ ${ }^{2}$ Korea University of Science and Technology, Daejeon 305-350, Republic of Korea \\ ${ }^{3}$ College of Pharmacy, Seoul National University, Seoul 151-742, Republic of Korea \\ Correspondence should be addressed to Sang Yoon Choi; sychoi@kfri.re.kr
}

Received 12 June 2015; Revised 23 July 2015; Accepted 29 July 2015

Academic Editor: Bartolo Gabriele

Copyright (C) 2015 Jin Taek Hwang et al. This is an open access article distributed under the Creative Commons Attribution License, which permits unrestricted use, distribution, and reproduction in any medium, provided the original work is properly cited.

\begin{abstract}
The potent suppression of adipocyte differentiation by 4-(4-methylbenzamino)benzoate was discovered during the search for new antiobesity compounds. 4-(4-methylbenzamino)benzoate was observed to suppress adipocyte differentiation in 3T3-L1 cells by $96.8 \%$ at $50 \mu \mathrm{M}$ without cytotoxicity. In addition, 4-(4-methylbenzamino)benzoate reduced the cellular expression of fatty acid synthase in a concentration-dependent manner, as well as suppressing PPAR-gamma activity, which controls fatty acid storage and glucose metabolism. Based on these results, 4-(4-methylbenzamino)benzoate shows potential as an antiobesity material.
\end{abstract}

\section{Introduction}

Obesity, a major factor in the development of heart disease, cancer, hypertension, diabetes, and degenerative arthritis, is induced by adipocyte differentiation due to hormonal changes and imbalances in energy metabolism caused by excessive fat intake [1-5]. Adipogenesis in the body is the process of cell differentiation by which preadipocytes become adipocytes during fat accumulation. Mature adipocytes are differentiated from immature adipocytes such as fibroblasts and form lipid droplets inside cells $[6,7]$.

Studies have shown that natural compounds, resveratrol and genistein, have antiobesity effects [8-11]. Resveratrol and genistein are contained in grapes and beans, respectively. Although some antiobesity drugs are currently available, such as orlistat, sibutramine, or sertraline, several side effects have been reported [12]. Thus, studies are being conducted on compounds with antiobesity effects to replace these drugs. In this study, the potent adipogenesis-suppressing activity of 4-(4-methylbenzamino)benzoate (MBAB, Figure 1) was observed in 3T3-L1 cells without cytotoxicity, during the search for new antiobesity substances. MBAB exhibited higher adipogenesis-suppressing activity compared to resveratrol or genistein. Therefore, MBAB show great potential as a new antiobesity substance.

\section{Materials and Methods}

2.1. Materials. MBAB was synthesized using a previously reported method [13]. Resveratrol and genistein, which were used as positive controls, were purchased from SigmaAldrich (St. Louis, MO, USA). The 3T3-L1 cells were purchased from American Type Culture Collection (Manassas, VA, USA) and the FAS antibodies from Cell Signaling Technology (Danvers, MA, USA).

2.2. Cell Culture and Differentiation. 3T3-L1 cells were cultured in DMEM culture medium with $10 \% \mathrm{FBS}$, at $37^{\circ} \mathrm{C}$, and $5 \% \mathrm{CO}_{2}$ conditions. For the differentiation, 3T3-L1 cells were grown in a 48-well plate until confluence, and differentiation was induced by incubation with a hormonal cocktail containing $10 \mu \mathrm{g} / \mathrm{mL}$ insulin, $0.5 \mu \mathrm{M}$ dexamethasone, and $0.5 \mu \mathrm{M}$ IBMX for $24 \mathrm{~h}$. The cells were then incubated with a normal medium containing $10 \mu \mathrm{g} / \mathrm{mL}$ insulin in the presence or absence of $\mathrm{MBAB}$, resveratrol, and genistein for 8 days. 
<smiles>COC(=O)c1ccc(NC(=O)c2ccc(C)cc2)cc1</smiles>

(a)<smiles>Oc1ccc(/C=C/c2cc(O)cc(O)c2)cc1</smiles>

(b)<smiles>O=c1c(-c2ccc(O)cc2)coc2cc(O)cc(O)c12</smiles>

(c)

Figure 1: Chemical structure of MBAB (a), resveratrol (b), and genistein (c).

2.3. Cell Viability. After differentiation was completed, $0.5 \mathrm{mg} / \mathrm{mL}$ of MTT [3-(4,5-dimethylthiazol-2-yl)-2,5-diphenyltetrazolium bromide] was added and incubated at $37^{\circ} \mathrm{C}$ for 4 hours. After eliminating the MTT solution, $200 \mu \mathrm{L}$ of DMSO was added and absorbance at $540 \mathrm{~nm}$ was measured to determine cell viability.

2.4. Oil Red O Staining and TG Assay. When differentiation was complete, the cells were washed with PBS twice and fixed with $3.7 \%$ formaldehyde. After incubating the cells for 1 hour using Oil Red O dye, isopropanol was added, and the absorbance was measured at $510 \mathrm{~nm}$ to determine the amount of triglycerides.

2.5. Fatty Acid Synthase (FAS) Expression. The 3T3-L1 cells were washed twice with ice-cold PBS and then lysed with a lysis buffer (50 mM Tris- $\mathrm{HCl}, 1 \%$ Triton X-100, 0.5\% sodium deoxycholate, $150 \mathrm{mM} \mathrm{NaCl}, 1 \mathrm{mM}$ EDTA, $1 \mathrm{mM}$ PMSF, $1 \mathrm{mM}$ sodium orthovanadate, $1 \mathrm{mM} \mathrm{NaF}$, and $0.2 \%$ protease inhibitor cocktail, pH 7.2). The collected protein was centrifuged at 14,000 rpm for 5 minutes, and the supernatant was collected for protein quantification. Then, $30 \mu \mathrm{g}$ of protein was loaded in 10\% SDS-PAGE for electrophoresis, after which it was transferred to a nitrocellulose membrane and reacted with FAS antibodies $(1: 1000)$, anti-mouse antibody $(1: 1000)$, and detected by ECL.

2.6. Peroxisome Proliferator-Activated Receptor $\gamma(P P A R-\gamma)$ Transcription Activity. The effect on PPAR- $\gamma$ activity in 3T3L1 cells was measured using a PPAR- $\gamma$ transcription factor assay kit (Cayman Chemical). The 3T3-L1 cells were treated with rosiglitazone and each concentration of $\mathrm{MBAB}$, and then the cell extract was added to a dsDNA sequence-coated plate. The PPAR $-\gamma$ antibodies and the secondary antibodies were reacted in order, and then a detection reagent was added and absorbance was measured at $450 \mathrm{~nm}$.

2.7. Statistical Analysis. All data were presented as mean \pm standard deviation (SD). The significance of the differences between groups was tested using one-way analysis of variance (ANOVA).

\section{Results and Discussion}

3.1. Effects on Cell Viability. The MTT assay showed that $\mathrm{MBAB}$ did not cause significant cell death at a concentration

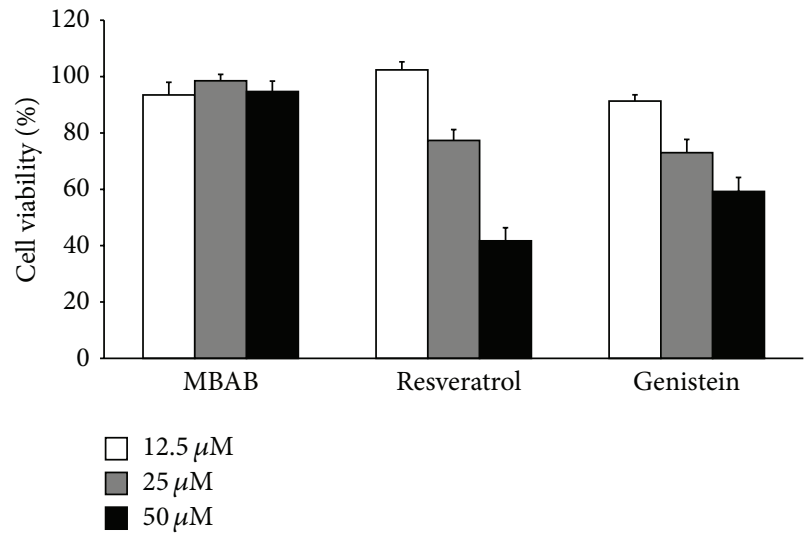

FIGURE 2: Effect on cell viability in 3T3-L1 cells. The cell viability of the vehicle was set at $100 \%$. The data represent the mean \pm SD of the triplicate experiments.

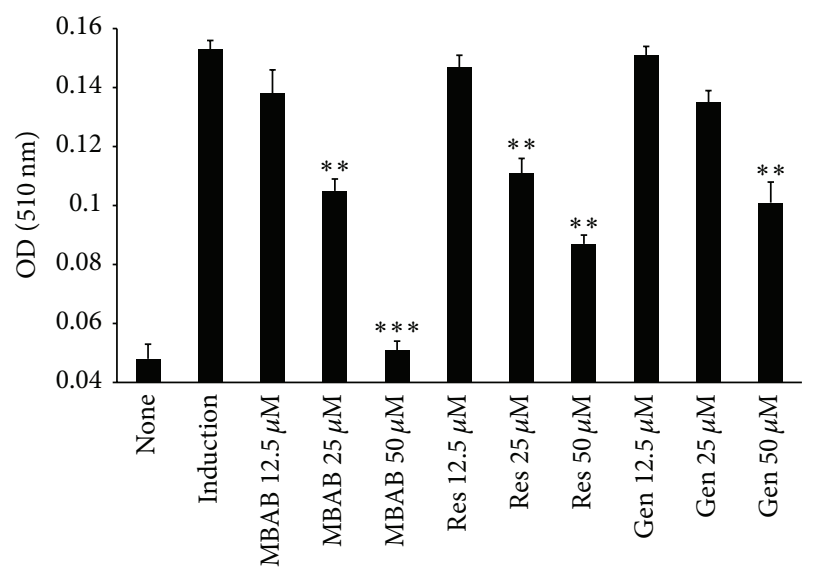

FIGURE 3: Inhibitory effects on 3T3-L1 adipocyte differentiation. Induction: hormone mixture, $\mathrm{MBAB}$ : hormone mixture $+\mathrm{MBAB}$, Res: hormone mixture + resveratrol, and Gen: hormone mixture + genistein. Three independent experiments were conducted. The results are expressed as the mean \pm SD of absorbance at $510 \mathrm{~nm}$. ${ }^{* *} P<0.01$ and ${ }^{* * *} P<0.001$ represent significant differences when comparing the hormone treatment group (induction group).

of less than $50 \mu \mathrm{M}$, whereas resveratrol and genistein reduced the cell viability in a concentration-dependent manner (Figure 2). Therefore, our results indicate that MBAB has lower cytotoxicity compared to resveratrol and genistein. 


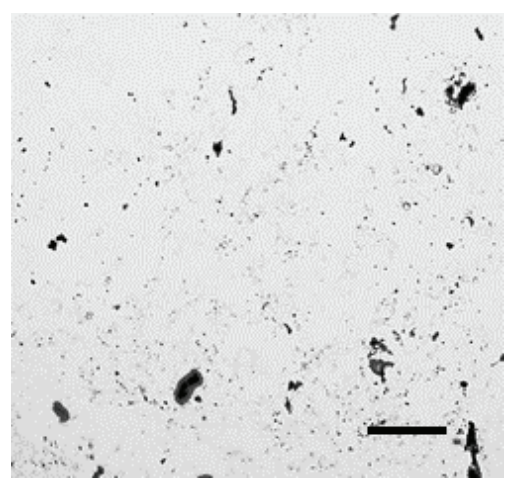

(a)

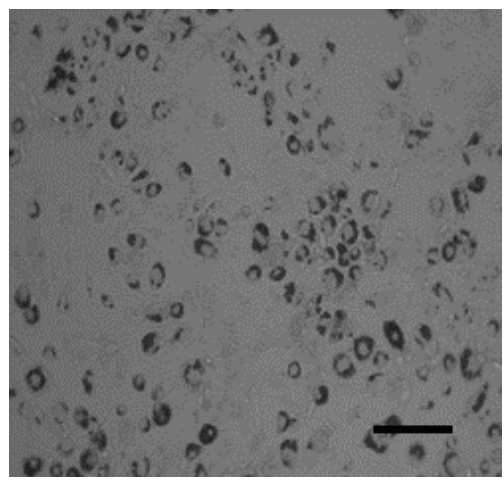

(d)

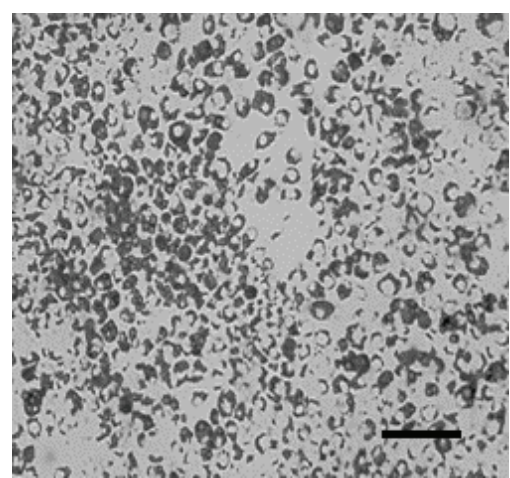

(b)

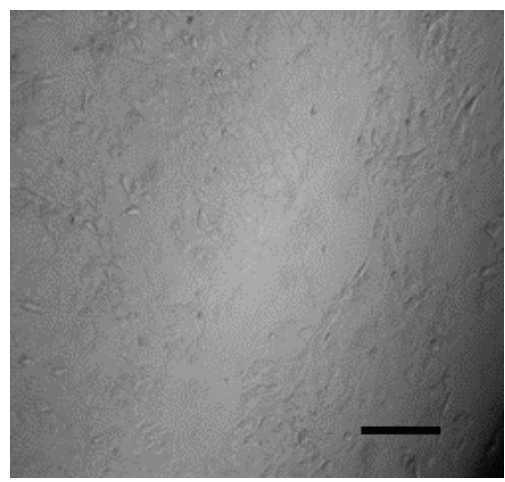

(e)

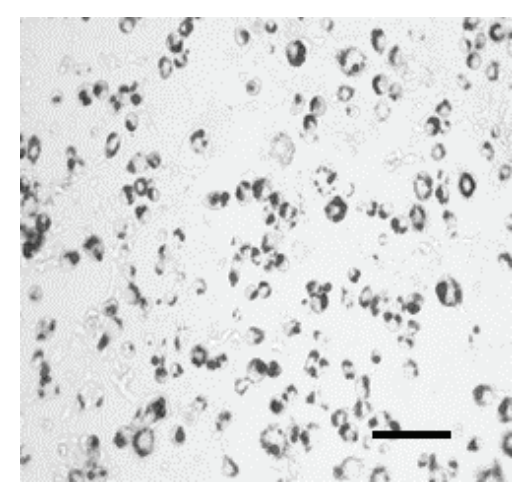

(c)

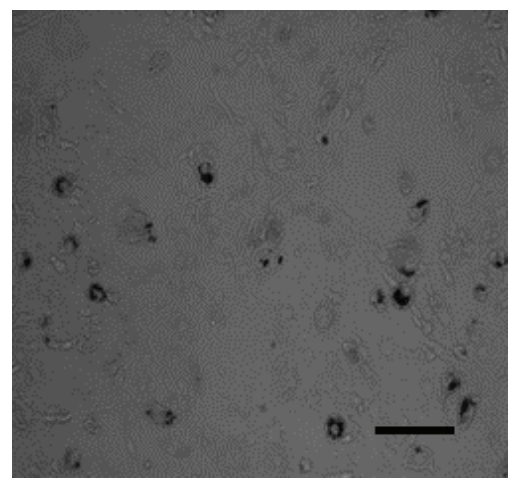

(f)

FIgURE 4: Photographs of 3T3-L1 adipocytes after Oil Red O staining. (a) Normal (control); (b) induction (hormone mixture); (c) induction (hormone mixture) $+12.5 \mu \mathrm{M}$ of MBAB; (d) induction (hormone mixture) $+25 \mu \mathrm{M}$ of MBAB; (e) induction (hormone mixture) $+50 \mu \mathrm{M}$ of $\mathrm{MBAB}$; (f) induction (hormone mixture) $+50 \mu \mathrm{M}$ of resveratrol. Scale bar $=50 \mu \mathrm{m}$.

3.2. Inhibitory Effects on Adipocyte Differentiation. After confirming the absence of cytotoxicity in 3T3-L1 cells treated with $\mathrm{MBAB}$ at concentrations of less than $50 \mu \mathrm{M}$, the effect on adipocyte differentiation was measured. As shown in Figure 3, MBAB suppressed the adipocyte differentiation of 3T3-L1 cells in a concentration-dependent manner after they were induced to differentiate after being treated with a hormone mixture. MBAB strongly suppressed adipocyte differentiation at a concentration of $50 \mu \mathrm{M}$, which was similar to the control group. In particular, MBAB exhibited a higher adipocyte differentiation suppressing activity at all concentrations compared to the same concentrations of resveratrol or genistein. Figure 4 shows photographs of 3T3-L1 cells treated with MBAB and stained with Oil Red O.

3.3. Inhibitory Effects on FAS Expression. Fatty acid is synthesized by the action of fatty acid synthase (FAS), an enzyme with a molecular weight of $250 \mathrm{kDa}$, using malonyl-CoA as substrate [14-17]. FAS is known as important factor in the regulation of fat biosynthesis and obesity. Thus, FAS inhibitors can effectively reduce fat production and suppress obesity.

The effect of MBAB on the intracellular expression of FAS was measured as shown in Figure 5. MBAB inhibited the increase in FAS production in 3T3-L1 cells that were induced by a hormone mixture in a concentration-dependent

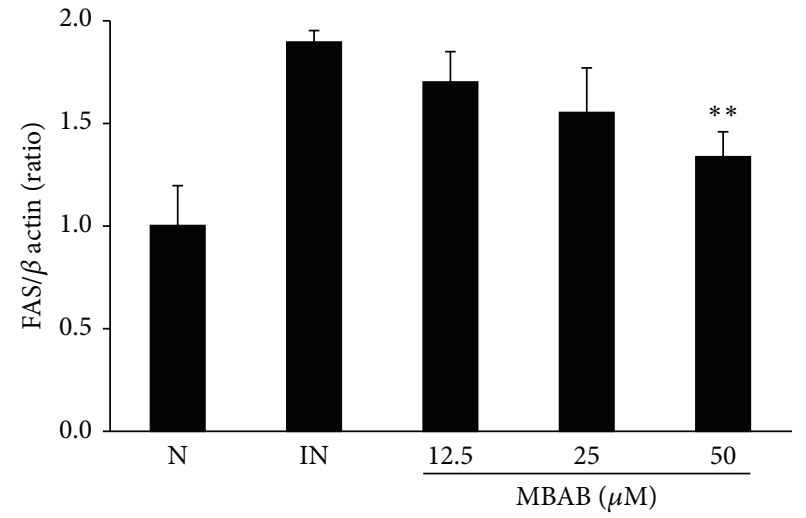

FigURE 5: Effect on intracellular FAS expression. N: normal; IN: hormone mixture; MBAB: hormone mixture + MBAB.

manner. Therefore, it is considered that MBAB impairs lipid production by suppressing fatty acid biosynthesis through FAS reduction.

3.4. Inhibitory Effects on PPAR- $\gamma$ Activity. PPAR- $\gamma$ regulates fatty acid storage and glucose metabolism [18]. Since the PPAR- $\gamma$ signaling pathway is known to be a major target for the development of antiobesity drugs, the effect of MBAB 


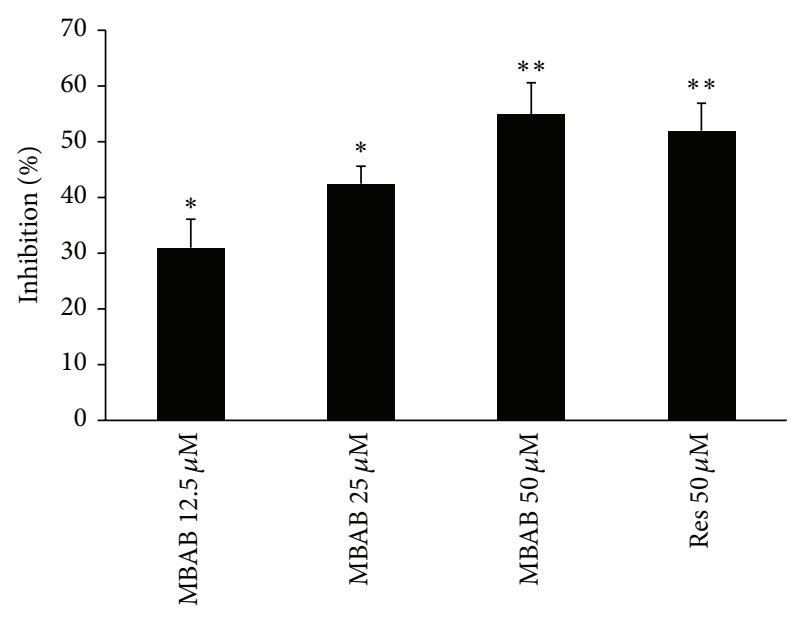

FIGURE 6: Inhibitory effect of MBAB on rosiglitazone induced PPAR- $\gamma$ transcriptional activity. Res: resveratrol. The data are the mean \pm SD values of the three experiments. ${ }^{*} P<0.05,{ }^{* *} P<0.01$ compared with the induction group (control).

on PPAR- $\gamma$ transcriptional activity was measured. The results show that MBAB suppressed rosiglitazone induced PPAR- $\gamma$ transcriptional activity in a concentration-dependent manner, and the degree of inhibition at $50 \mu \mathrm{M}$ was $55 \%$ compared to control (Figure 6).

\section{Conflict of Interests}

The authors declare that there is no conflict of interests regarding the publication of this paper.

\section{References}

[1] K. F. Adams, A. Schatzkin, T. B. Harris et al., "Overweight, obesity, and mortality in a large prospective cohort of persons 50 to 71 years old," The New England Journal of Medicine, vol. 355, no. 8, pp. 763-778, 2006.

[2] T. B. Horwich and G. C. Fonarow, "Glucose, obesity, metabolic syndrome, and diabetes relevance to incidence of heart failure," Journal of the American College of Cardiology, vol. 55, no. 4, pp. 283-293, 2010.

[3] P. Strazzullo, L. D’Elia, G. Cairella, F. Garbagnati, F. P. Cappuccio, and L. Scalfi, "Excess body weight and incidence of stroke: meta-analysis of prospective studies with 2 million participants," Stroke, vol. 41, no. 5, pp. e418-e426, 2010.

[4] B. C. T. Field, O. B. Chaudhri, and S. R. Bloom, "Obesity treatment: novel peripheral targets," British Journal of Clinical Pharmacology, vol. 68, no. 6, pp. 830-843, 2009.

[5] J. Roth, A. L. Szulc, and A. Danoff, "Energy, evolution, and human diseases: an overview," The American Journal of Clinical Nutrition, vol. 93, no. 4, pp. 875-883, 2011.

[6] E. D. Rosen and B. M. Spiegelman, "Molecular regulation of adipogenesis," Annual Review of Cell and Developmental Biology, vol. 16, pp. 145-171, 2000.

[7] W. Kiess, S. Petzold, M. Töpfer et al., "Adipocytes and adipose tissue," Best Practice \& Research: Clinical Endocrinology \& Metabolism, vol. 22, no. 1, pp. 135-153, 2008.
[8] M. Zhang, K. Ikeda, J.-W. Xu, Y. Yamori, X.-M. Gao, and B.-L. Zhang, "Genistein suppresses adipogenesis of 3T3-L1 cells via multiple signal pathways," Phytotherapy Research, vol. 23, no. 5, pp. 713-718, 2009.

[9] K. Szkudelska and T. Szkudelski, "Resveratrol, obesity and diabetes," European Journal of Pharmacology, vol. 635, no. 1-3, pp. 1-8, 2010.

[10] C. A. Baile, J.-Y. Yang, S. Rayalam et al., "Effect of resveratrol on fat mobilization," Annals of the New York Academy of Sciences, vol. 1215, no. 1, pp. 40-47, 2011.

[11] N. Behloul and G. Wu, "Genistein: a promising therapeutic agent for obesity and diabetes treatment," European Journal of Pharmacology, vol. 698, no. 1-3, pp. 31-38, 2013.

[12] M. Li and B. M. Cheung, "Rise and fall of anti-obesity drugs," World Journal of Diabetes, vol. 2, no. 2, pp. 19-23, 2011.

[13] S. Hwang, S. Y. Choi, J. H. Lee et al., "Identification of a potent and noncytotoxic inhibitor of melanin production," Bioorganic \& Medicinal Chemistry, vol. 18, no. 15, pp. 5602-5609, 2010.

[14] S. Kreuz, C. Schoelch, L. Thomas, W. Rist, J. F. Rippmann, and H. Neubauer, "Acetyl-CoA carboxylases 1 and 2 show distinct expression patterns in rats and humans and alterations in obesity and diabetes," Diabetes/Metabolism Research and Reviews, vol. 25, no. 6, pp. 577-586, 2009.

[15] S. J. Wakil and L. A. Abu-Elheiga, "Fatty acid metabolism: target for metabolic syndrome," Journal of Lipid Research, vol. 50, pp. 138-143, 2009.

[16] G. V. Ronnett, E.-K. Kim, L. E. Landree, and Y. Tu, "Fatty acid metabolism as a target for obesity treatment," Physiology \& Behavior, vol. 85, no. 1, pp. 25-35, 2005.

[17] M. J. Wolfgang and M. D. Lane, "The role of hypothalamic malonyl-CoA in energy homeostasis," The Journal of Biological Chemistry, vol. 281, no. 49, pp. 37265-37269, 2006.

[18] S. I. Anghel, E. Bedu, C. D. Vivier, P. Descombes, B. Desvergne, and W. Wahli, "Adipose tissue integrity as a prerequisite for systemic energy balance: a critical role for peroxisome proliferatoractivated receptor $\gamma$," The Journal of Biological Chemistry, vol. 282, no. 41, pp. 29946-29957, 2007. 

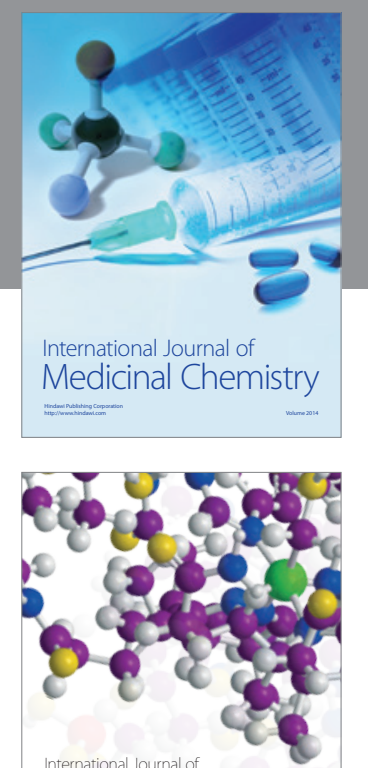

\section{Carbohydrate} Chemistry

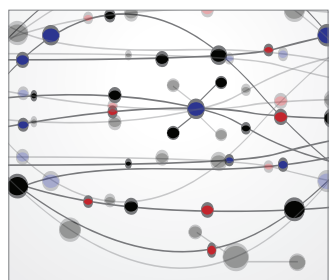

The Scientific World Journal
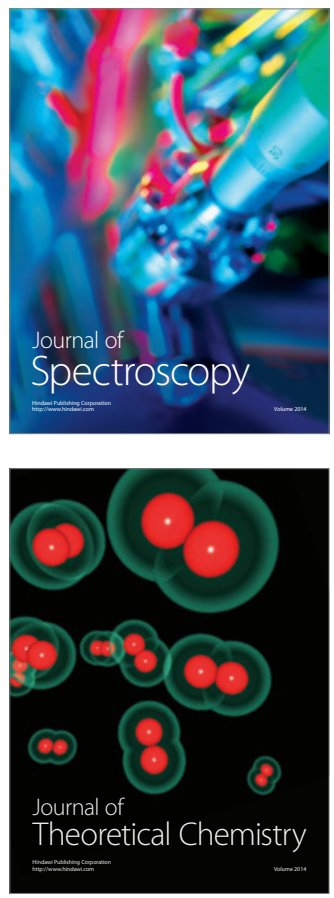
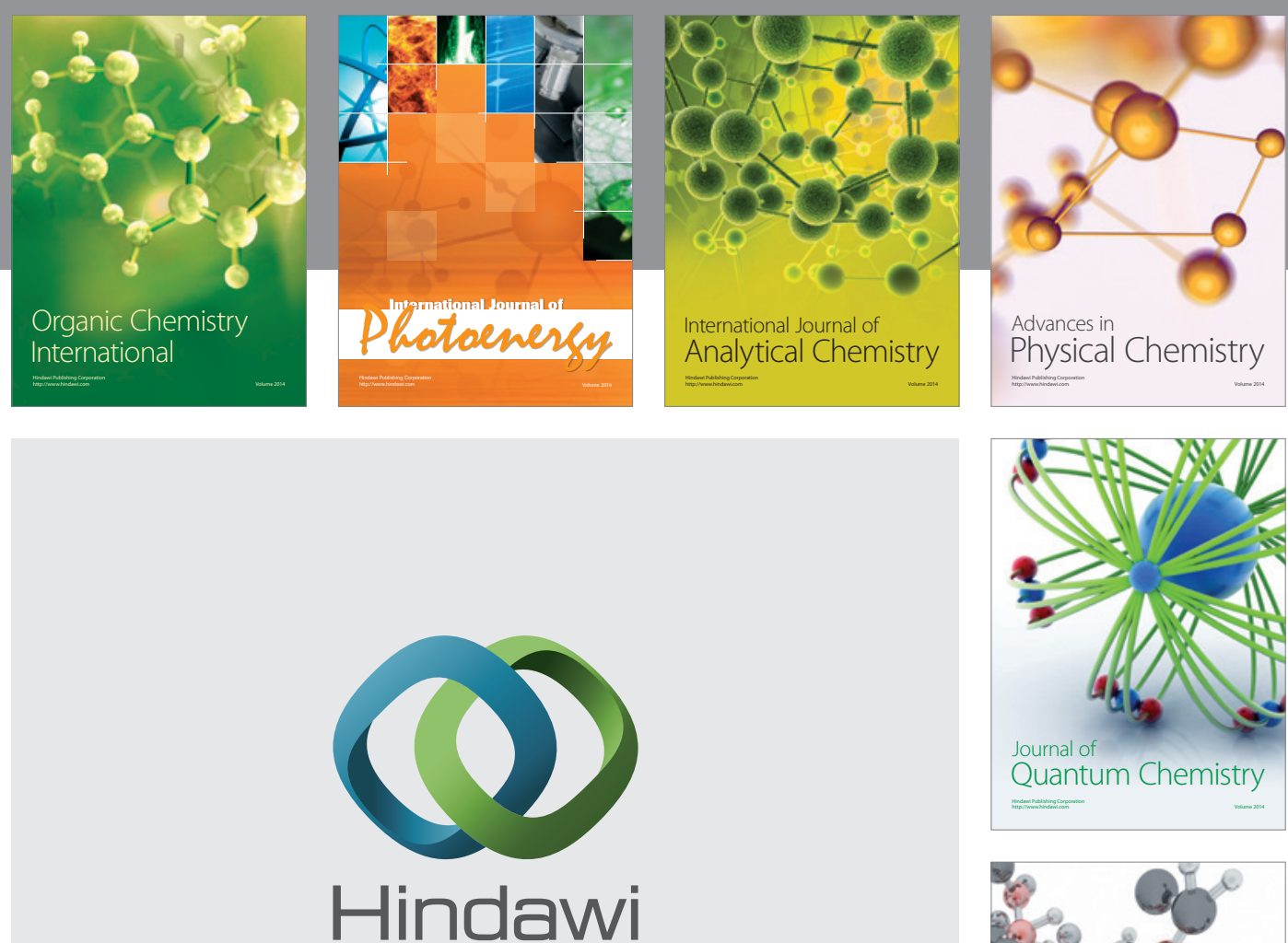

Submit your manuscripts at

http://www.hindawi.com

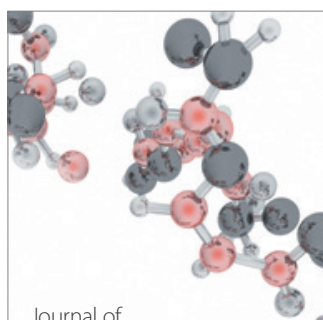

Analytical Methods

in Chemistry

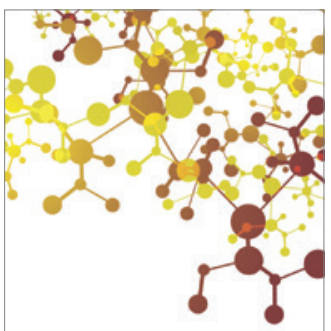

Journal of

Applied Chemistry

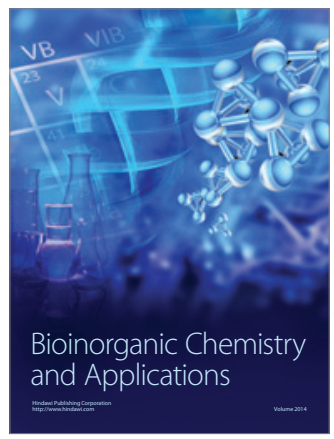

Inorganic Chemistry
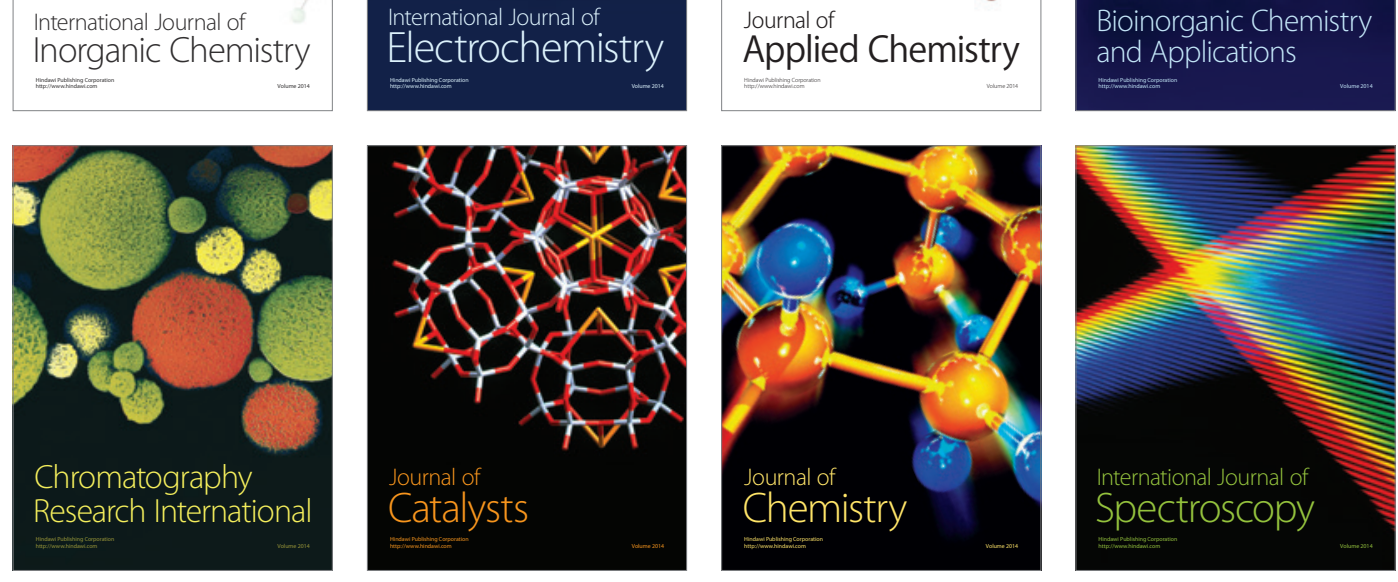